\title{
Multidecadal trends in the nesting phenology of Pacific and Atlantic leatherback turtles are associated with population demography
}

\author{
Nathan J. Robinson ${ }^{1, *}$, Sara E. Valentine ${ }^{2}$, Pilar Santidrián Tomillo ${ }^{3,4}$, \\ Vincent S. Saba ${ }^{5}$, James R. Spotila ${ }^{6}$, Frank V. Paladino ${ }^{2,4}$ \\ ${ }^{1}$ Department of Biological Sciences, Purdue University, West Lafayette, Indiana 47907, USA \\ ${ }^{2}$ Department of Biology, Indiana University-Purdue University Fort Wayne, Fort Wayne, Indiana 46805, USA \\ ${ }^{3}$ Population Ecology Group, Institut Mediterrani d'Estudis Avançats, IMEDEA (CSIC-UIB), Miquel Marquès, 21, 07190 \\ Esporles, Mallorca, Spain \\ ${ }^{4}$ The Leatherback Trust, Goldring-Gund Marine Biology Station, Playa Grande, Guanacaste, Costa Rica \\ ${ }^{5}$ National Oceanic and Atmospheric Administration, National Marine Fisheries Service, Northeast Fisheries Science Center \\ c/o Geophysical Fluid Dynamics Laboratory, 201 Forrestal Road, Princeton University Forrestal Campus, Princeton, New \\ Jersey 08540, USA \\ ${ }^{6}$ Department of Biology, Drexel University, Philadelphia, Pennsylvania 19104, USA
}

\begin{abstract}
Knowledge of the mechanisms influencing phenology can provide insights into the adaptability of species to climate change. Here, we investigated the factors influencing multidecadal trends in the nesting phenology of the leatherback turtle Dermochelys coriacea at Playa Grande, Costa Rica, in the eastern Pacific Ocean and at Sandy Point, US Virgin Islands, in the western Atlantic Ocean. Between 1993 and 2013, the median nesting date (MND) at Playa Grande occurred later, at a rate of $\sim 0.3 \mathrm{~d} \mathrm{yr}^{-1}$. In contrast, between 1982 and 2010, the MND at Sandy Point occurred earlier, at a rate of $\sim 0.17 \mathrm{~d} \mathrm{yr}^{-1}$. The opposing trends in the MND of each population were not explained by variation in the multivariate El Niño-Southern Oscillation index, North Atlantic Oscillation index, or Atlantic Multidecadal Oscillation index; however, the MND at Playa Grande was significantly correlated with nesting population size. We propose that changes in demography, linked to the population decline at Playa Grande, and the population recovery at Sandy Point may explain the contrasting trends in MNDs. If the observed trends in MND continue into the future, the nesting season at Playa Grande will coincide with increasingly adverse conditions for hatching success, exacerbating the already detrimental effects of climate change. Alternatively, shifts in the nesting phenology may make the Atlantic populations more resilient to climate change. Our findings highlight the increasing need for conservation efforts for eastern Pacific leatherback turtles to consider climate change mitigation practices.
\end{abstract}

KEY WORDS: Dermochelys coriacea $\cdot$ Nesting season $\cdot$ ENSO $\cdot$ NAO $\cdot$ MEI $\cdot$ Population size Resale or republication not permitted without written consent of the publisher

\section{INTRODUCTION}

As global temperatures continue to rise, there is increasing concern over the ability of organisms to adapt to these changes (Hoffmann \& Sgrò 2011, Doney et al. 2012, Pike 2014). A potential plastic response to climate change is a shift in the timing of seasonal biological phenomena, termed phenology (Parmesan 2006). By migrating and reproducing when seasonal weather patterns are cooler, many migratory species have mitigated some of the detrimental effects of a warming climate on reproductive success (Møller et al. 2008). Yet such adaptive trends are not universal among species (Both et al. 2009) or 
even populations (Gordo 2007). Understanding why different populations express divergent responses to climate change requires an understanding of the factors governing the phenology of a species (Gienapp et al. 2007). Moreover, such knowledge is necessary for developing bioclimatic envelope models with the capacity to accurately predict the response of a species to climate change at regional, or even global, scales (Guisan \& Thuiller 2005).

Sea turtles nest on tropical and sub-tropical beaches during distinct nesting seasons that generally last between 3 and 6 mo. The timing of the nesting season must, at least partially, coincide with seasonal temperature and precipitation patterns that create suitable conditions for incubating eggs on the beach (Pike 2013). As climate change progresses, however, shifts in phenology may be required to maintain the nesting season within optimal beach conditions. Indeed, a recent climate-forced population model for the eastern Pacific leatherback turtle Dermochelys coriacea predicted that the anticipated reduction in hatching success resulting from a warming climate could be partially offset if the nesting season shifts to earlier in the year when conditions are cooler and wetter (Saba et al. 2012). Incubation temperatures also govern the gender of the developing hatchlings, with females being produced at higher temperatures (Binckley et al. 1998). Shifts in nesting phenology could therefore have the additional benefit of counteracting female-biases in hatchling production (Doody et al. 2006). However, no previous studies have investigated whether leatherback turtles are likely to respond to climate change though adaptive shifts in nesting phenology.

The factors governing nesting phenology have only been investigated for only 2 sea turtle species: loggerhead turtles Caretta caretta (Weishampel et al. 2004, Pike et al. 2006, Mazaris et al. 2013) and green turtles Chelonia mydas (Pike 2009, Weishampel et al. 2010, Dalleau et al. 2012). For both species, it has been repeatedly shown that the timing of the nesting season is influenced by the sea surface temperature of the waters near the nesting grounds (e.g. Weishampel et al. 2004, 2010, Mazaris et al. 2008, Dalleau et al. 2012). However, leatherback turtles are uniquely able among sea turtles to maintain elevated and constant body temperatures through a series of adaptations termed gigantothermy (Paladino et al. 1990, Southwood et al. 2005, Bostrom \& Jones 2007). The effect of temperature on the nesting phenology of leatherback turtles may therefore be less distinct. Consequently, determining the factors influencing leatherback nesting phenology likely requires the in- vestigation of a broader range of oceanographic variables. Furthermore, even though local climate conditions directly affect hatching success (Santidrián Tomillo et al. 2009, 2012), environmental conditions at the nesting beach are unlikely to govern when a turtle will arrive at the nesting beach, although they may do so over long time scales through natural selection (Berteaux et al. 2004). This is because leatherback turtles conduct extensive reproductive migrations, and the distance between nesting grounds and foraging areas can extend across entire ocean basins (Benson et al. 2011, Witt et al. 2011). As a result, the nesting grounds are often physically disconnected from the climate of the foraging area.

Leatherback turtles forage exclusively on gelatinous zooplankton, a polyphyletic taxon whose distribution is strongly tied to physical oceanographic conditions (Graham et al. 2001). As a result, the broad-scale distribution and abundance of gelatinous zooplankton are often tied to large oceanographic phenomena, such as the El Niño-Southern Oscillation (ENSO; Raskoff 2001), North Atlantic Oscillation (NAO; Lynam et al. 2004), and the Atlantic Multidecadal Oscillation (AMO; Edwards et al. 2013). Such oceanographic phenomena are therefore also linked to foraging success in leatherback turtles (Saba et al. 2007, Reina et al. 2009). Moreover, the relationships observed between oceanographic conditions and the onset of migration towards the nesting grounds has led to the hypothesis that turtles foraging in more productive areas are able to acquire resources more rapidly, allowing them to migrate to their nesting grounds earlier (Saba et al. 2007, Sherrill-Mix et al. 2008). In addition, as leatherback turtles are expected to forage while migrating (Lambardi et al. 2008), a decrease in food availability en route could result in increased time spent searching for food and a longer migration duration. Better foraging conditions could even increase the number of clutches that each female lays in the upcoming nesting season. This would extend the length of time that each turtle spends at the nesting grounds and may even extend the length of the nesting season.

Beyond the impacts of foraging success, nesting phenology may also be related to factors such as population size or structure (Votier et al. 2009, Shirai 2013). Larger populations of Dalmatian pelicans Pelecanus crispus and great white pelicans Pelecanus onocrotalus nest earlier than smaller populations (Doxa et al. 2012). In many birds, older individuals also tend to nest earlier in the year than younger individuals (Hipfner et al. 2010). Similar trends have been observed in leatherback turtles, as older and/or 
more experienced individuals tend to arrive earlier to nest and lay more clutches (Santidrián Tomillo et al. 2009, Rafferty et al. 2011). As a result, populations with an older mean age may have both earlier and longer lasting nesting seasons (Ezard et al. 2007).

In the present study, we investigated the nesting phenology of 2 leatherback turtle populations over multiple decades. Firstly, we determined whether there had been a change in the timing or length of the nesting season over the study period. Secondly, we investigated whether interannual patterns in nesting phenology were influenced by oceanographic conditions experienced prior to departing the foraging area, while departing the foraging area, during migration, or after arriving at the nesting grounds. Thirdly, we investigated whether nesting phenology was affected by population size. Lastly, to discern how any shifts in nesting phenology may be influencing the conditions experienced by the developing nests, we compared historic trends in nesting phenology to local air temperatures and precipitation levels.

We obtained nesting data from 2 of the longest tagging programs for nesting leatherback turtles: Playa Grande, Costa Rica $\left(10^{\circ} 20^{\prime} \mathrm{N}, 8^{\circ} 51^{\prime} \mathrm{W}\right)$, in the eastern Pacific Ocean and Sandy Point, US Virgin Islands $\left(17^{\circ} 40^{\prime} \mathrm{N}, 64^{\circ} 52^{\prime} \mathrm{W}\right)$, in the western Atlantic Ocean. We chose these 2 sites because both support longterm ( $\geq 20$ yr) tagging programs, are located in separate ocean basins, and have experienced contrasting population trends in recent years, with the population decreasing at Playa Grande (Santidrián Tomillo et al. 2007, F. V. Paladino unpubl. data) and increasing at Sandy Point (Dutton et al. 2005, USFWS unpubl. data). By investigating 2 distinct populations, we aimed to investigate differences in the capacity of leatherback turtles from either the Pacific or Atlantic Ocean to respond to climate change via adaptive shifts in nesting phenology.

\section{MATERIALS AND METHODS}

\section{Study sites}

Playa Grande is a sandy beach, $3.6 \mathrm{~km}$ long, on the Pacific coast of Costa Rica. Playa Grande is part of a 3-beach complex, along with nearby Playa Ventanas (1 km long) and Playa Langosta (1.3 km), all of which are used by substantial numbers of nesting leatherback turtles (Reina et al. 2002). Together, these beaches host an estimated $70 \%$ of the entire leatherback population nesting on the eastern Pacific shores of Costa Rica and have the highest density of nesting leatherback turtles in the eastern Pacific Ocean. Of these 3 beaches, Playa Grande has supported the longest running monitoring program for leatherback turtles (since 1993/94) and has the majority of the nesting activity (70 to $90 \%$; Reina et al. 2002). In the present study, we thus exclusively used data collected on Playa Grande.

Sandy Point is a dynamic sandy beach $(3.0 \mathrm{~km}$ long) on the coast of St. Croix, US Virgin Islands, in the Atlantic Ocean. A tagging program for nesting leatherback turtles at Sandy Point has been in place since 1978. Even though consistent saturation tagging (the concept of identifying every nesting turtle on a specified beach) has only been achieved since 1982, this still remains one of the longest running saturation tagging programs for leatherback turtles worldwide.

\section{Nesting dates}

At both locations, the nesting season began in the coolest month of the year and lasted for approximately $6 \mathrm{mo}$; at Playa Grande, the nesting season was between October and March, while at Sandy Point it was between March and August. Over the nesting season, the beaches were patrolled nightly to encounter nesting females as well as to count and identify tracks of missed turtles. In this manner, a track was recorded for every sea turtle emergence even if the turtle itself was not encountered.

For logistical reasons, the start and end dates of the monitoring programs differed between years. We accounted for this sampling bias by cropping the available datasets to include only the longest consistently patrolled sampling period for all of the years in the study. For Playa Grande, this was between 1 November and 10 February (a total of 132 d) from 1994/95 until 2011/12, and for Sandy Point, this was between 1 April and 5 July (95 d) from 1982 until 2010.

Differences in the monitoring methodologies between Playa Grande and Sandy Point affected our ability to calculate nightly nesting activity. At Playa Grande, observers recorded whether or not a track contained a body-pit, i.e. a large disturbance in the sand that is formed during the initial stages of the nesting process. At Playa Grande, around $10 \%$ of the turtles were missed and only a body-pit was seen. Although it is difficult to confirm whether a leatherback turtle nested from visual inspection of only its tracks, body-pits were readily identifiable from the tracks, and $90 \%$ of body pits were shown to result in a nest (Reina et al. 2002). Consequently, we used 
body-pit counts as our measure of nesting activity at Playa Grande. At Sandy Point, it was not the practice to record from a track whether a body-pit was made or not. Therefore, we used confirmed nest counts (where the turtle was witnessed laying) as our measure of nesting activity at Sandy Point. At this location, less than $5 \%$ of turtles were missed each year.

Using the daily body-pit counts at Playa Grande and daily nest counts at Sandy Point, we calculated the median nesting date (MND). We added $1 \mathrm{~d}$ to the median nesting dates during each leap year. We also calculated the standard deviation of the mean nesting date. We termed this measure the central tendency of the nesting season $\left(\mathrm{CT}_{\mathrm{ns}}\right)$. As sea turtle nesting seasons can be roughly fit to a normal distribution (Girondot et al. 2007), the $\mathrm{CT}_{\mathrm{ns}}$ could be used as a proxy for the length of the nesting season.

\section{Ocean conditions}

We compared the MND and $\mathrm{CT}_{\mathrm{ns}}$ to the multivariate ENSO index (MEI) for turtles nesting at Playa Grande, and to the NAO and AMO indices for turtles nesting at Sandy Point. These oceanographic indices provide a univariate representation of oceanographic conditions within the Pacific or Atlantic Oceans. Values for the MEI, NAO, and AMO were accessed from www.esrl.noaa.gov/psd/enso/mei/, www.cpc.ncep. noaa.gov/products/precip/CWlink/pna/nao_index. html, and www.esrl.noaa.gov/psd/data/correlation/ amon.us.data, respectively.

To determine whether oceanographic conditions influence the $\mathrm{MND}$ and $\mathrm{CT}_{\mathrm{ns}}$, we chose to average the MEI or NAO over discrete periods of time that would best coincide with different parts of the migratory cycle. To this extent, we averaged the MEI and NAO over 4 discrete 3 mo periods that encompassed the year preceding the month of peak nesting, which was December for Playa Grande and May for Sandy Point. From earliest to latest, the 3 mo periods represented the conditions (1) before departure from the foraging areas, (2) during departure from the foraging areas, (3) during migration from foraging to nesting grounds, and (4) upon arrival at the nesting grounds. These 3 mo time periods were chosen because post-nesting leatherback turtles require between 2 and 6 mo to reach their foraging areas (James et al. 2005, Shillinger et al. 2008) and leatherback turtles generally only nest every 2 to 7 years (Reina et al. 2002). Thus we assumed that the prenesting migrations would take a similar length of time and remain in their foraging grounds for many months before returning to their nesting areas. Furthermore, the nesting seasons at Playa Grande and Sandy Point last around $6 \mathrm{mo}$, with the majority of turtles arriving in the first 3 mo.

\section{Population size}

At Playa Grande and Sandy Point, passive integrated transponder (PIT) tags with unique ID numbers were implanted into every turtle encountered over the nesting season. As leatherback turtles nest an average of 7 times per nesting season (Reina et al. 2002 ) and there was a $~ 90$ to $95 \%$ encounter rate for nesting turtles at Playa Grande and Sandy Point, respectively, there is only a nominal probability that a turtle would be missed in a given season. Thus, these tagging data provide an accurate representation of the number of nesting individuals each year.

\section{Local air temperature and rainfall}

Monthly air temperatures and rainfall for Playa Grande and Sandy Point were obtained from the Daniel Oduber Quiros International Airport (44 km from the nesting site) via the National Meteorological Institute of Costa Rica. For Sandy Point, these data were obtained from the Christiansted Hamilton Field Airport (10 km from the nesting site) via www.ncdc. noaa.gov/cdo-web/datasets/GHCNDMS/stations/ GHCND:VQW00011624/detail. We calculated the mean monthly air temperature and total precipitation over the 6 mo nesting season.

\section{Statistical analyses}

We tested whether there had been a change in the $\mathrm{MND}, \mathrm{CT}_{\mathrm{ns}}$, local air temperature, or local precipitation over the study period using least-squares linear regression. To compare the effects of ocean conditions before departure from foraging areas, ocean conditions during departure from foraging areas, ocean conditions during migration to nesting grounds, ocean condition on arrival at nesting grounds, and nesting population size on the MND and $\mathrm{CT}_{\mathrm{ns}}$, we used a generalized linear model with a Gaussian variance function and an identity link function. We compared these models using Akaike's information criterion (AIC). Data were analyzed using program $\mathrm{R}$ ( $\mathrm{R}$ Development Core Team). For all statistical tests, $\alpha=0.05$. 


\section{RESULTS}

At Playa Grande between 1993-94 and 2012-13, the MND shifted to later in the season at a rate of approximately $0.31 \mathrm{~d} \mathrm{yr}^{-1}$, totaling a shift of $6 \mathrm{~d}$ (Fig. 1a). This shift was close to statistical significance $\left(r^{2}=0.17 ; p=0.07\right)$. The MND was highly variable with a range of $17 \mathrm{~d}$. Much of this range was attributed to atypically late MNDs that occurred in 1993-94, 2002-03, and 2008-09. At Sandy Point, the MND shifted to earlier in the season at a rate of approximately $0.17 \mathrm{~d} \mathrm{yr}^{-1}$, totaling a shift of $5 \mathrm{~d}$ over $29 \mathrm{yr}$ (Fig. 1c). While this shift was smaller than that at Playa Grande, it was statistically significant $\left(\mathrm{r}^{2}=\right.$ $0.14, \mathrm{p}<0.01$ ). The total range of MNDs at Sandy Point was $14 \mathrm{~d}$.

We found no significant correlations between the MND at Playa Grande and the MEI, yet there was a significant negative correlation between population size and the MND at Playa Grande ( $p<0.01$; Table 1, Fig. 2a). Furthermore, the AIC indicated that the best model for predicting MND included population size as the only variable (see Table $\mathrm{S} 1$ in the Supplement at www.int-res.com/articles/suppl/n024p197_supp. pdf). No significant correlations were found between the MND at Sandy Point and the NAO, AMO, or population size (Table 1, Fig. 2b).

At both locations, the $\mathrm{CT}_{\mathrm{ns}}$ showed no significant change (Playa Grande: $\mathrm{r}^{2}=0.02, \mathrm{p}=0.53$; Sandy Point: $r^{2}=0.04, p=0.32$; Fig. $\left.1 b, d\right)$. However, significant negative correlations were observed between the $\mathrm{CT}_{\mathrm{ns}}$ at Playa Grande and the MEI during migration ( $p=0.03)$ and the $\mathrm{CT}_{\mathrm{ns}}$ at Sandy Point and the NAO during departure $(p<0.01$; Table 1, Fig. 3a,b).

At Playa Grande, neither local air temperatures $\left(\mathrm{r}^{2}<0.01, \mathrm{p}=0.77\right)$ nor precipitation levels $\left(\mathrm{r}^{2}<0.01\right.$, $\mathrm{p}=0.97$ ) showed any significant changes over the study period (see Fig. S1 in the Supplement). The local air temperatures at Sandy Point decreased significantly $\left(\mathrm{r}^{2}=0.28, \mathrm{p}<0.01\right)$, but the observed decrease in precipitation levels was not significant $\left(\mathrm{r}^{2}=0.04, \mathrm{p}=0.22\right)$.

At both sites, there was a large change in the size of the nesting population over the study period,
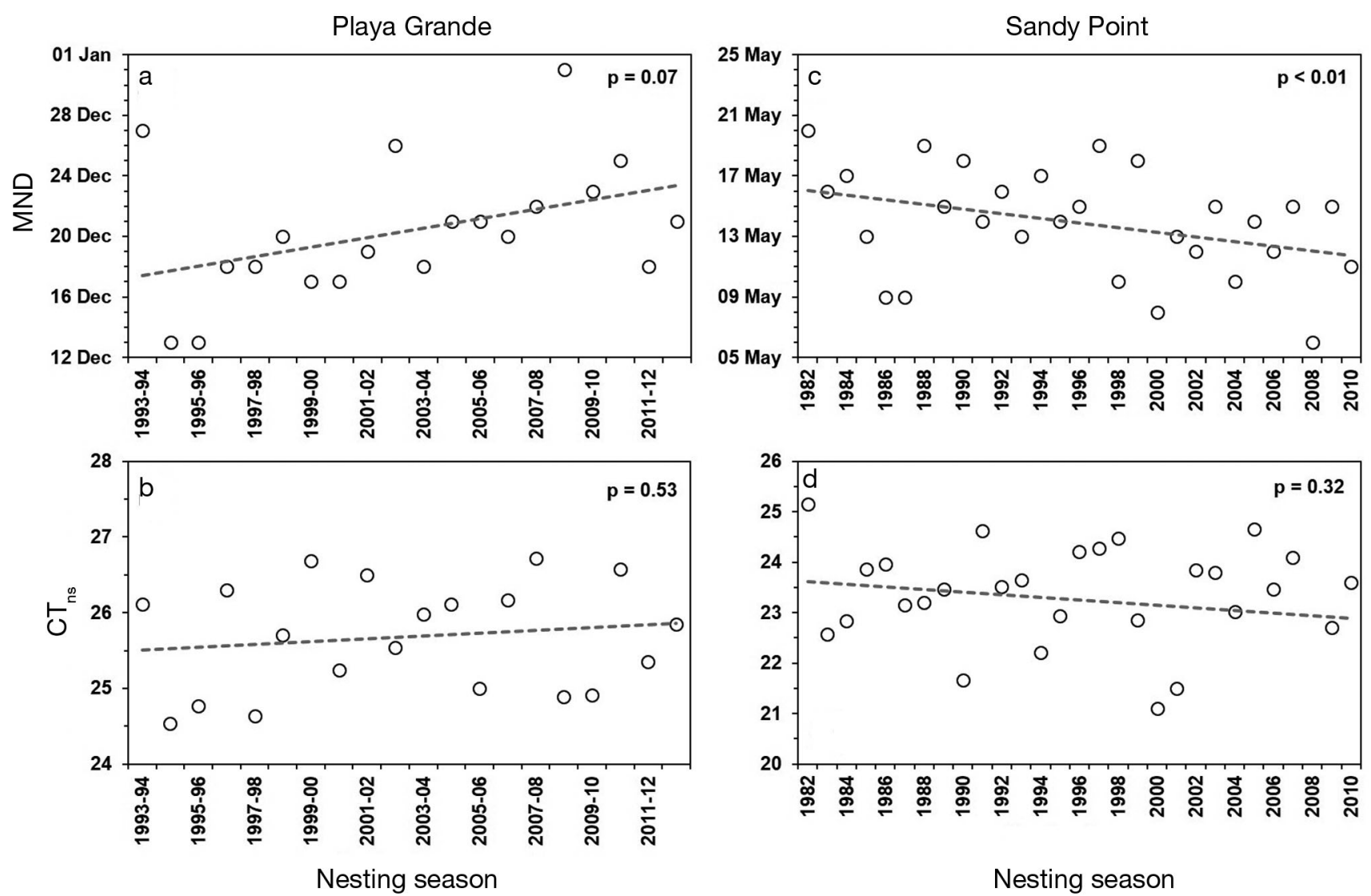

Fig. 1. Interannual trends in $(\mathrm{a}, \mathrm{c})$ the median nesting date $(\mathrm{MND})$ and $(\mathrm{b}, \mathrm{d})$ the central tendency of the nesting season $\left(\mathrm{CT}_{\mathrm{nsi}}\right.$ see 'Materials and methods: Nesting dates') for leatherback turtles Dermochelys coriacea at (a,b) Playa Grande, Costa Rica (Pacific Ocean) and (c,d) Sandy Point, US Virgin Islands (Atlantic Ocean). Dashed lines represent linear trend lines 
which was evident beyond the substantial interannual fluctuations. The number of turtles nesting per year at Playa Grande decreased from $\sim 300$ at the beginning of this study to $\sim 30$ at the end. In contrast, the number of turtles nesting per year at Sandy Point increased from $\sim 20$ to $\sim 150$.

Table 1. Comparison of median nesting date (MND) and central tendency of the nesting season $\left(\mathrm{CT}_{\text {nsi }}\right.$ see 'Materials and methods: Nesting dates') for leatherback turtles Dermochelys coriacea at Playa Grande, Costa Rica (Pacific Ocean), and Sandy Point, US Virgin Islands (Atlantic Ocean), to oceanographic conditions using a generalized linear model with a Gaussian variance function and an identity link function. MEI: Multivariate El Niño-Southern Oscillation index; NAO: North Atlantic Oscillation index; AMO: Atlantic Multidecadal Oscillation index. Each index was averaged over periods that represented the time before departure from the foraging area, during departure from the foraging area, during migration between foraging and nesting areas, and upon arrival at the nesting areas. Asterisks $\left({ }^{*}\right)$ denote a significant correlation $(\alpha=0.05)$

\begin{tabular}{|c|c|c|c|c|c|c|}
\hline \multirow[t]{3}{*}{ Variable } & \multirow{2}{*}{\multicolumn{2}{|c|}{$\begin{array}{l}\text { Playa Grande } \\
\text { MEI- }\end{array}$}} & \multirow{2}{*}{\multicolumn{2}{|c|}{$\longrightarrow_{\mathrm{NAO}}$ Sand }} & \multicolumn{2}{|c|}{ Point } \\
\hline & & & & & $-\mathrm{A}$ & - \\
\hline & $t$ & $\mathrm{p}$ & $t$ & $\mathrm{p}$ & $t$ & $\mathrm{p}$ \\
\hline \multicolumn{7}{|l|}{ MND } \\
\hline Before departure & -0.07 & 0.95 & 0.71 & 0.72 & $<0.01$ & 0.93 \\
\hline Departure & 0.50 & 0.63 & 0.06 & 0.06 & 0.02 & 0.45 \\
\hline Migration & -0.29 & 0.78 & 0.39 & 0.39 & 0.03 & 0.38 \\
\hline Arrival & -0.32 & 0.75 & 0.60 & 0.60 & 0.08 & 0.14 \\
\hline Combined & -0.30 & 0.77 & 0.94 & 0.94 & 0.07 & 0.15 \\
\hline Population size & -3.39 & $<0.01^{*}$ & 0.67 & 0.57 & & \\
\hline \multicolumn{7}{|l|}{$\mathrm{CT}_{\mathrm{ns}}$} \\
\hline Before departure & -0.51 & 0.64 & 0.94 & 0.17 & 0.18 & 0.74 \\
\hline Departure & -1.03 & 0.32 & 0.43 & $<0.01^{*}$ & 0.12 & 0.93 \\
\hline Migration & -2.35 & $0.03^{*}$ & 0.37 & 0.10 & 0.21 & 0.62 \\
\hline Arrival & -1.96 & 0.07 & 0.14 & 0.99 & 0.12 & 0.94 \\
\hline Combined & -1.59 & 0.13 & 0.14 & 0.21 & 0.12 & 0.87 \\
\hline Population size & -1.93 & 0.07 & 1.05 & 0.41 & & \\
\hline
\end{tabular}

\section{DISCUSSION}

Here, we examined multidecadal trends in the nesting phenology of 2 populations of leatherback turtles inhabiting different ocean basins. To determine which factors govern nesting phenology for each population, we compared the observed trends in MND and $\mathrm{CT}_{\mathrm{ns}}$ to ocean conditions experienced at different phases of migration as well as nesting population size. We also compared past trends in the MND to conditions at the nesting beach, to determine how such phenological changes may affect conditions for incubating nests. This information provided insights into the capacity of different leatherback turtle populations to adapt to future climate change through shifts in the timing of the nesting season.

Over the study period, the MND at Playa Grande occurred later, at a rate of $0.31 \mathrm{~d} \mathrm{yr}^{-1}$. In contrast, the MND at Sandy Point occurred earlier, at a rate of $0.17 \mathrm{~d} \mathrm{yr}^{-1}$. Such shifts in nesting phenology are relatively slow compared to other sea turtle species at higher-latitude nesting beaches (e.g. Weishampel et al. 2004, Pike et al. 2006, Mazaris et al. 2013). Moreover, the shift observed at Playa Grande is the first time a shift for nesting later in the year has been reported for any sea turtle population.
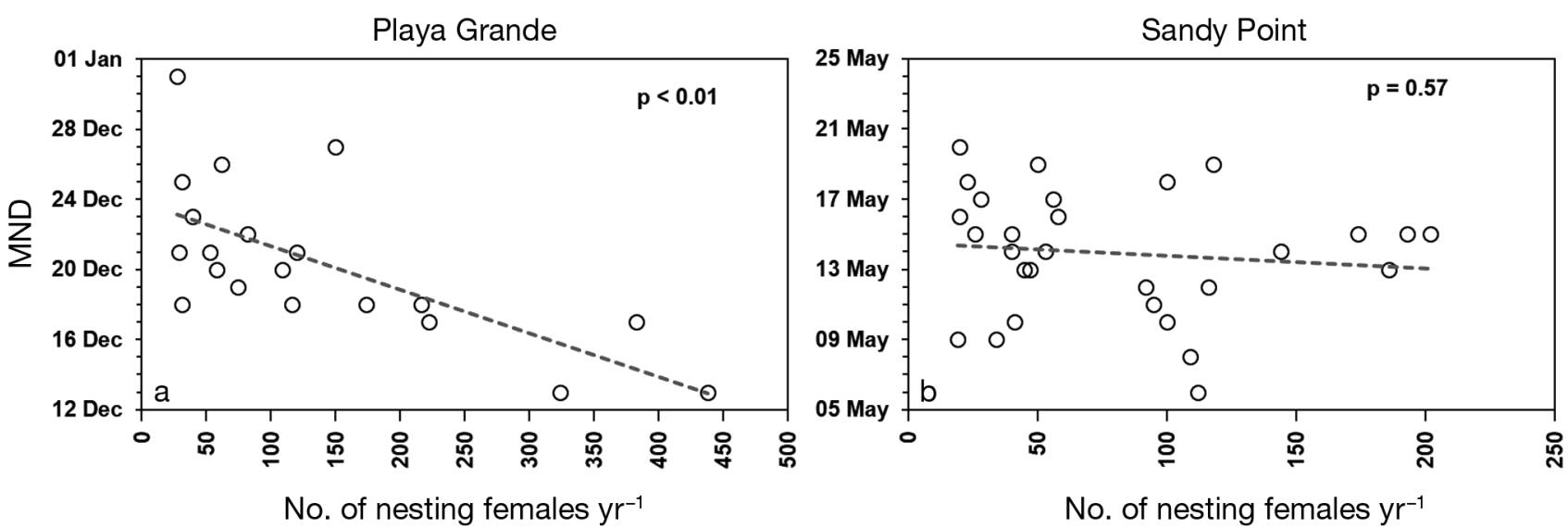

Fig. 2. Comparison of the median nesting date (MND) of leatherback turtles Dermochelys coriacea to nesting population size at (a) Playa Grande (Pacific Ocean) and (b) Sandy Point (Atlantic Ocean). Dashed lines represent linear trend lines 

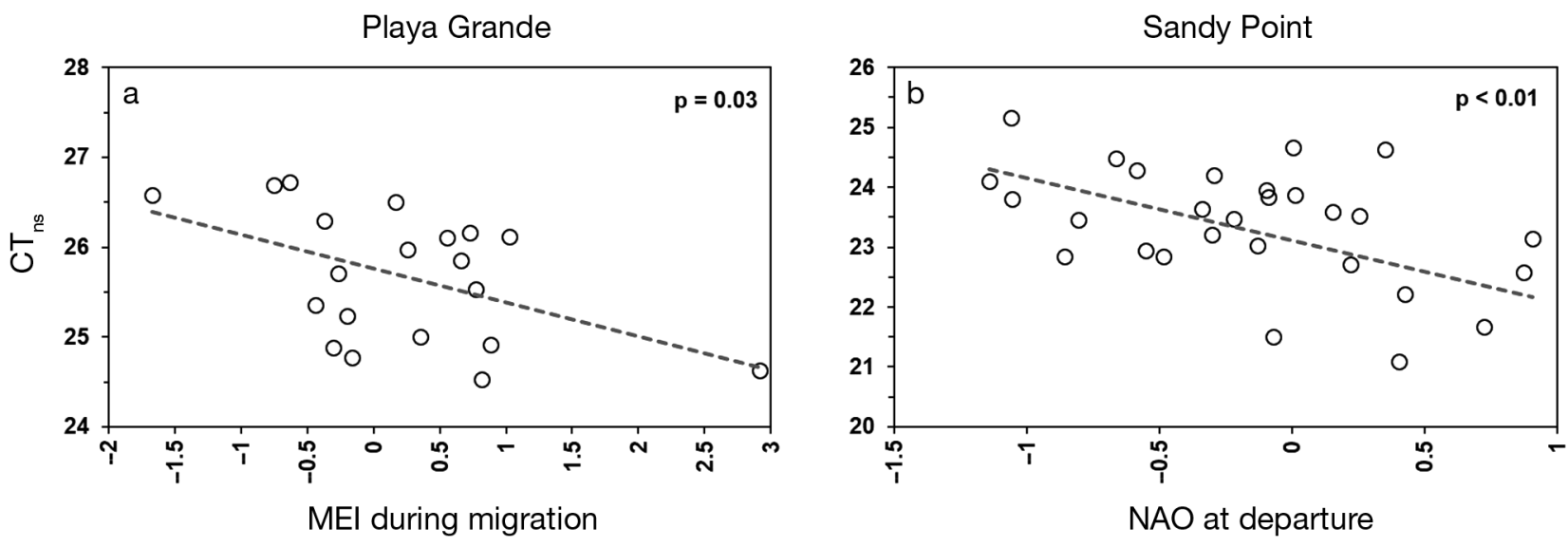

Fig. 3. Comparison of the central tendency of the nesting season $\left(\mathrm{CT}_{\mathrm{ns}}\right)$ for leatherback turtles Dermochelys coriacea and oceanographic conditions during specific sections of their post-nesting migrations. (a) At Playa Grande, the comparison between the contrary tendency of the nesting season and the multivariate El Niño-Southern Oscillation index (MEI) during the migration between foraging areas and nesting grounds is shown. (b) At Sandy Point, the comparison between the contrary tendency of the nesting season and the North Atlantic Oscillation (NAO) index during departure from the foraging areas is shown. Dashed lines represent linear trend lines

The strongest correlation with MND was observed between nesting population size and MND at Playa Grande. Although the shift in the nesting phenology at Playa Grande over time was not significant, this trend is likely to continue if the population continues to decline. In addition, no significant correlation was observed between population size and the MND at Sandy Point. We therefore hypothesize that the changes in nesting phenology may not be driven by population size specifically, but by changes in population demography. Specifically, the trends may be caused by changes in the ratio of younger and later nesting turtles to more experienced, and earlier nesting, turtles. Between the mid-1970s and early 1990s, approximately $90 \%$ of all the eggs laid at Playa Grande were poached (Santidrián Tomillo et al. 2008). As leatherback turtles are estimated to reach sexual maturity between 9 and 16 yr (Zug \& Parham 1996, Jones et al. 2011), the resulting 'missing' generation should have begun nesting between the mid-1980s and early 2000s. Consequently, in 1993 at Playa Grande, the beginning of our study period, a large portion of the younger and later nesting individuals were absent. Yet over time, as the hatchlings from nests protected from poaching became reproductively mature, this younger generation of nesting turtles should again reappear in the population and this should shift the MND to later in the year. This shift in the average age of the population at Playa Grande may even be compounded by the increasingly high levels of adult mortality suffered by this population due to incidental take by fisheries (Spotila et al. 2000, Lewison et al. 2004), which would also reduce the av- erage age of the population. In contrast, at Sandy Point, there has been a marked increase in the population of nesting leatherback turtles since the early 1980s (Dutton et al. 2005). As this increase was largely a product of increased recruitment into the population, the average age of the nesting population has probably remained low or only increased slightly, thus potentially explaining the lack of a correlation between population size and MND at Sandy Point.

At both Playa Grande and Sandy Point, we found no correlation between the MND and the MEI and NAO or AMO, respectively. Such results are surprising considering that oceanographic conditions have previously been linked to the departure date of prenesting leatherback turtles from their foraging areas in the waters of eastern Canada (Sherrill-Mix et al. 2008). However, that study investigated satellitetracked individuals and thus was able to examine the oceanographic conditions directly at the animal's location. In our study, we did not know the exact location of the turtles prior to nesting so we chose to use indices that provide a coarse-representation of ocean conditions over entire ocean basins, specifically the MEI, NAO, and AMO. Our decision to use such broad-scale oceanographic factors may have masked the actual effect of ocean conditions on the MND. Thus, we recommend that future studies attempt to focus their investigation onto areas within known high-use leatherback turtle habitats, such as the eastern portion of the South Pacific Gyre for turtles from Playa Grande (Shillinger et al. 2011) or the waters of eastern Canada for the turtles from Sandy Point (Fossette et al. 2010). 
The only correlations we found between oceanographic conditions and nesting phenology were between the MEI and NAO and $\mathrm{CT}_{\text {ns }}$ of nesting season at Playa Grande and Sandy Point, respectively. Specifically, $\mathrm{CT}_{\mathrm{ns}}$ at Playa Grande was negatively correlated with the MEI during the migration period, and $\mathrm{CT}_{\text {ns }}$ at Sandy Point was negatively correlated with the NAO during the departure period. Positive values of the MEI are generally associated with lower food availability for leatherback turtles in the Pacific Ocean (Saba et al. 2007, Reina et al. 2009), and similar patterns might also be true for the NAO in the Atlantic Ocean (Attrill et al. 2007). When less food is available to pre-nesting turtles, they might not be able to brood as many eggs and thus lay fewer clutches on arrival at the nesting grounds, leading to a shorter nesting season. Alternatively, if food is more patchily distributed then this could also lead to greater variation in departure dates and, in turn, also arrival dates.

\section{CONSERVATION IMPLICATIONS}

At both Playa Grande and Sandy Point, beach temperatures increase over the season (Santidrián Tomillo et al. 2009; see Fig. S2 in the Supplement). Consequently, nests laid later in the season are exposed to hotter and drier conditions and have lower hatching success and emergence rates (Santidrián Tomillo et al. 2009). At Playa Grande, where the nesting season is shifting to later in the year, this means that an increasing portion of the population will experience fatally hot and dry conditions and hatchling output will decrease. Even though no increase in local temperature has been recorded over the past $20 \mathrm{yr}$, declines in hatchling output are likely to be further exacerbated by future climate change (Santidrián Tomillo et al. 2012) as global temperatures are expected to increase by approximately $2^{\circ} \mathrm{C}$ before the end of this century (Stocker et al. 2013).

In contrast to the leatherback turtles nesting in Playa Grande, those nesting at Sandy Point may be able to better persist under conditions of climate change due to the observed shifts in nesting phenology. Indeed, so far the MND at Sandy Point is shifting towards cooler conditions at the beginning of the nesting season. Local air temperatures have even decreased over the past 29 yr. However, this does not mean that populations at Sandy Point are safe from the effect of climate change over long time scales. Shifts in nesting phenology may not continue indefinitely if they are ultimately controlled by demogra- phy, and even the lowest seasonal temperatures will eventually rise if current trends persist with climate change.

If population demography does have a significant influence on nesting phenology, a method to facilitate beneficial shifts in nesting phenology may be possible. Specifically, conservation efforts that focus on reducing adult mortality may have the additional benefit of increasing the average age of the nesting population. More experienced, older individuals also tend to nest earlier and so this could shift the MND to earlier in the year. Yet it must be noted that the shifts observed in our study are small and, thus, shifts in nesting phenology may not be rapid enough to offset the future impacts of rapid climate change. Instead, the conservation of leatherback turtles, especially in the Pacific Ocean where populations are already severely depleted (Spotila et al. 2000, Tapilatu et al. 2013), may have to rely on additional proactive measures to reduce incubation temperatures for eggs through direct manipulation of environmental conditions, e.g. watering or shading nests (Patino-Martinez et al. 2012).

Acknowledgements. The data analyzed in this study were collected by researchers and volunteers working at Parque Marino Nacional Las Baulas and Sandy Point Wildlife Refuge. The US Fish and Wildlife Service (USFWS) provided access to the data from Sandy Point. Funding for the project at Playa Grande was provided by the Earthwatch Institute, The Betz Chair Endowment of Drexel University, The Schrey Chair Endowment of Indiana University-Purdue University Fort Wayne, and The Leatherback Trust. Funding for the project at Sandy Point was provided by the USFWS Division of Refuges, the National Marine Fisheries Service-Southwest Science Center, West Indies Marine Animal Research and Conservation Service, USFWS Section 6 appropriations administered through the Virgin Islands Department of Planning and Natural Resources, and the EarthWatch Institute. Research and animal care permits for the project at Playa Grande were provided by MINEAT and the Animal Care Committee of Drexel University and Indiana University-Purdue University Fort Wayne. Research and animal care permits for the project at Sandy Point were provided by the Department of Planning and Natural Resources and the USFWS. Samir H. Patel, Claudia Lombard, Jeffrey Seminoff and 3 anonymous reviewers provided critical feedback that helped to improve this manuscript.

\section{LITERATURE CITED}

Attrill MJ, Wright J, Edwards M (2007) Climate-related increases in jellyfish frequency suggest a more gelatinous future for the North Sea. Limnol Oceanogr 52:480-485

Benson SR, Eguchi T, Foley DG, Forney KA and others (2011) Large-scale movements and high-use areas of western Pacific leatherback turtles, Dermochelys coriacea. Ecosphere 2:art84 
Berteaux D, Réale D, McAdam AG, Boutin S (2004) Keeping pace with fast climate change: Can Arctic life count on evolution? Integr Comp Biol 44:140-151

Binckley CA, Spotila JR, Wilson KS, Paladino FV (1998) Sex determination and sex ratios of Pacific leatherback turtles Dermochelys coriacea. Copeia 1998:291-300

Bostrom BL, Jones DR (2007) Exercise warms adult leatherback turtles. Comp Biochem Physiol A Mol Integr Physiol 147:323-331

Both C, Van Asch M, Bijlsma RG, Van Den Burg AB, Visser ME (2009) Climate change and unequal phenological changes across four trophic levels: constraints or adaptations? J Anim Ecol 78:73-83

> Dalleau M, Ciccione S, Mortimer JA, Garnier J, Benhamou S, Bourjea J (2012) Nesting phenology of marine turtles: insights from a regional comparative analysis on green turtle (Chelonia mydas). PLoS ONE 7:e46920

> Doney SC, Ruckelshaus M, Duffy JE, Barry JP and others (2012) Climate change impacts on marine ecosystems. Annu Rev Mar Sci 4:11-37

> Doody JS, Guarino E, Georges A, Corey C, Murray G, Ewert M (2006) Nesting site choice compensates for climate effects on sex ratios in a lizard with environmental sex determination. Evol Ecol 20:307-330

> Doxa A, Robert A, Crivelli A, Catsadorakis G and others (2012) Shifts in breeding phenology as a response to population size and climate change: a comparison between short- and long-distance migrant species. Auk 129:753-762

Dutton DL, Dutton PH, Chaloupka M, Boulon RH (2005) Increase of a Caribbean leatherback turtle Dermochelys coriacea nesting population linked to long-term nest protection. Biol Conserv 126:186-194

Edwards M, Beaugrand G, Helaouët P, Alheit J, Coombs S (2013) Marine ecosystem response to the Atlantic Multidecadal Oscillation. PLoS ONE 8:e57212

Ezard THG, Becker PH, Coulson T (2007) Correlations between age, phenotype, and individual contribution to population growth in common terns. Ecology 88: 2496-2504

> Fossette S, Girard C, López-Mendilaharsu M, Miller P and others (2010) Atlantic leatherback migratory paths and temporary residence areas. PLoS ONE 5:e13908

Gienapp P, Leimu R, Merilä J (2007) Responses to climate change in avian migration time - microevolution versus phenotypic plasticity. Clim Res 35:25-35

Girondot M, Godfrey MH, Ponge L, Rivalan P (2007) Modeling approaches to quantify leatherback nesting trends in French Guiana and Suriname. Chelonian Conserv Biol 6: $37-46$

> Gordo O (2007) Why are bird migration dates shifting? A review of weather and climate effects on avian migratory phenology. Clim Res 35:37-58

Graham WM, Pagès F, Hamner WM (2001) A physical context for gelatinous zooplankton aggregations: a review. Hydrobiologia 451:199-212

Guisan A, Thuiller W (2005) Predicting species distribution: offering more than simple habitat models. Ecol Lett 8: 993-1009

> Hipfner JM, McFarlane-Tranquilla LA, Addison B (2010) Experimental evidence that both timing and parental quality affect breeding success in a zooplanktivorous seabird. Auk 127:195-203

> Hoffmann AA, Sgrò CM (2011) Climate change and evolutionary adaptation. Nature 470:479-485
James MC, Myers RA, Ottensmeyer CA (2005) Behaviour of leatherback sea turtles, Dermochelys coriacea, during the migratory cycle. Proc R Soc Lond B Biol Sci 272: 1547-1555

> Jones TT, Hastings MD, Bostrom BL, Pauly D, Jones DR (2011) Growth of captive leatherback turtles, Dermochelys coriacea, with inferences on growth in the wild: implications for population decline and recovery. J Exp Mar Biol Ecol 399:84-92

> Lambardi P, Lutjeharms JRE, Mencacci R, Hays GC, Luschi $P$ (2008) Influence of ocean currents on long-distance movement of leatherback sea turtles in the Southwest Indian Ocean. Mar Ecol Prog Ser 353:289-301

Lewison RL, Crowder LB, Freeman S (2004) Quantifying the effects of fisheries on threatened species: the impact of pelagic longlines on loggerhead and leatherback sea turtles. Ecol Lett 7:221-231

> Lynam CP, Hay SJ, Brierly AS (2004) Interannual variability in abundance of North Sea jellyfish and links to the North Atlantic Oscillation. Limnol Oceanogr 49:637-643

Mazaris AD, Kallimanis AS, Sgardelis SP, Pantis JD (2008) Do long-term changes in sea surface temperature at the breeding areas affect the breeding dates and reproductive performance of Mediterranean loggerhead turtles? Implications for climate change. J Exp Mar Biol Ecol 367: 219-226

> Mazaris AD, Kallimanis AS, Pantis JD, Hays GC (2013) Phenological response of sea turtles to environmental variation across a species' northern range. Proc R Soc Lond B Biol Sci 280:20122397

Møller AP, Rubolini D, Lehikoinen E (2008) Populations of migratory bird species that did not show a phenological response to climate change are declining. Proc Natl Acad Sci USA 105:16195-16200

Paladino FV, O'Connor MP, Spotila JR (1990) Metabolism of leatherback turtles, gigantothermy and thermoregulation of dinosaurs. Nature 344:858-860

> Parmesan C (2006) Ecological and evolutionary responses to recent climate change. Annu Rev Ecol Evol Syst 37: 637-669

Patino-Martinez J, Marco A, Quiñones L, Hawkes L (2012) A potential tool to mitigate the impacts of climate change to the Caribbean leatherback sea turtle. Glob Change Biol 18:401-411

> Pike DA (2009) Do green turtles modify their nesting seasons in response to environmental temperature? Chelonian Conserv Biol 8:43-47

Pike DA (2013) Climate influences the global distribution of sea turtle nesting. Glob Ecol Biogeogr 22:555-556

Pike DA (2014) Forecasting the viability of sea turtle eggs in a warming world. Glob Change Biol 20:7-15

Pike DA, Antworth RL, Stiner JC (2006) Earlier nesting contributes to short nesting seasons for the loggerhead sea turtle, Caretta caretta. J Herpetol 40:91-94

> Rafferty AR, Santidrián Tomillo P, Spotila JR, Paladino FV, Reina RD (2011) Embryonic death is linked to maternal identity in the leatherback turtle (Dermochelys coriacea). PLoS ONE 6:e21038

> Raskoff K (2001) The impact of El Niño events on populations of mesopelagic hydromedusae. Hydrobiologia 451: $121-129$

Reina RD, Mayor PA, Spotila JR, Piedra R, Paladino FV (2002) Nesting ecology of the leatherback turtle, Dermochelys coriacea, at Parque Nacional Marino Las Baulas, Costa Rica: 1988-1989 to 1999-2000. Copeia 2002:653-664 
Reina RD, Spotila JR, Paladino FV, Dunham AE (2009) Changed reproductive schedule of eastern Pacific leatherback turtles Dermochelys coriacea following the 1997-98 El Niño to La Niña transition. Endang Species Res 7:155-161

Saba VS, Santidrián-Tomillo P, Reina RD, Spotila JR, Musick JA, Evans DA, Paladino FV (2007) The effect of the El Niño Southern Oscillation on the reproductive frequency of eastern Pacific leatherback turtles. J Appl Ecol 44:395-404

Saba VS, Stock CA, Spotila JR, Paladino FV, Santidrián Tomillo P (2012) Projected response of an endangered marine turtle population to climate change. Nature Clim Change 2:814-820

Santidrián Tomillo P, Vélez E, Reina RD, Piedra R, Paladino FV, Spotila JR (2007) Reassessment of the leatherback turtle (Dermochelys coriacea) nesting population at Parque Nacional Marino Las Baulas, Costa Rica: effects of conservation efforts. Chelonian Conserv Biol 6:54-62

Santidrián Tomillo P, Saba VS, Piedra R, Paladino FV, Spotila JR (2008) Effects of illegal harvest of eggs on the population decline of leatherback turtles in Las Baulas Marine National Park, Costa Rica. Conserv Biol 22: 1216-1224

Santidrián Tomillo P, Suss JS, Wallace BP, Magrini KD, Blanco G, Paladino FV, Spotila JR (2009) Influence of emergence success on the annual reproductive output of leatherback turtles. Mar Biol 156:2021-2031

Santidrián Tomillo P, Saba VS, Blanco GS, Stock CA, Paladino FV, Spotila JR (2012) Climate driven egg and hatchling mortality threatens survival of Eastern Pacific leatherback turtles. PLoS ONE 7:e37602

Sherrill-Mix SC, James MC, Myers RA (2008) Migration cues and timing in leatherback sea turtles. Behav Ecol 19:231-236

Shillinger GL, Palacios DM, Bailey H, Bograd SJ and others (2008) Persistent leatherback turtle migrations present opportunities for conservation. PLoS Biol 6:e171

Shillinger GL, Swithenbank AM, Bailey H, Bograd SJ and others (2011) Vertical and horizontal habitat preferences

Editorial responsibility: Jeffrey Seminoff, La Jolla, California, USA of post-nesting leatherback turtles in the South Pacific Ocean. Mar Ecol Prog Ser 422:275-289

Shirai T (2013) Colony development and density-dependent processes in breeding grey herons. Int J Zool 13:404065

$>$ Southwood AL, Andrews RD, Paladino FV, Jones DR (2005) Effects of diving and swimming behavior on body temperatures of Pacific leatherback turtles in tropical seas. Physiol Biochem Zool 78:285-297

Spotila JR, Reina RD, Steyermark AC, Plotkin PT, Paladino FV (2000) Pacific leatherback turtles face extinction. Nature 405:529-530

Stocker TF, Qin D, Plattner GK, Tignor MMB and others (eds) (2013) Climate Change 2013: the physical science basis. Working Group I contribution to the Fifth Assessment Report of the Intergovernmental Panel on Climate Change. Available at www.ipcc.ch/report/ar5/wg1/ (accessed 5 February 2014)

Tapilatu RF, Dutton PH, Tiwari M, Wibbels T, Ferdinandus HV, Iwanggin WG, Nugroho BH (2013) Long-term decline of the western Pacific leatherback, Dermochelys coriacea: a globally important sea turtle population. Ecosphere 4:art25, http://dx.doi.org/10.1890/ES12-00348.1

> Votier SC, Hatchwell BJ, Mears M, Birkhead TR (2009) Changes in the timing of egg-laying of a colonial seabird in relation to population size and environmental conditions. Mar Ecol Prog Ser 393:225-233

> Weishampel JF, Bagley DA, Ehrhart LM (2004) Earlier nesting by loggerhead sea turtles following sea surface warming. Glob Change Biol 10:1424-1427

> Weishampel JF, Bagley DA, Ehrhart LM, Weishampel AC (2010) Nesting phenologies of two sympatric sea turtle species related to sea surface temperatures. Endang Species Res 12:41-47

Witt MJ, Bonguno EA, Broderick AC, Coyne MS and others (2011) Tracking leatherback turtles from the world's largest rookery: assessing threats across the South Atlantic. Proc R Soc Lond B Biol Sci 278:2338-2347

Zug GR, Parham J (1996) Age and growth in leatherback turtles, Dermochelys coriacea (Testudines: Dermochelyidae): a skeletochronological analysis. Chelonian Conserv Biol 2:244-249

Submitted: November 12, 2013; Accepted: March 25, 2014 Proofs received from author(s): 27 May, 2014 